\section{Membership Structure, Competition, and Occupational Credit Union Deposit Rates}

\author{
William R. Emmons and \\ Frank A. Schmid
}

H ow do credit unions set deposit rates? As we will show, the answer to this question depends on (i) who actually makes business decisions in credit unions (who is in control), and (ii) whether local deposit market conditions are important. Although members legally control all credit unions, an occupational credit union requires a sponsor (i.e., an employer) that could withdraw its support from the credit union or apply pressure on members if the sponsor's interests were not being served. Thus, the question of who effectively controls an occupational credit union is an empirical question.

If members effectively control an occupational credit union, then the array of services offered and the pricing of these services may be skewed toward the interests of a subset of members. This is because, in a one-member, one-vote governance system, there is a strong "winner-takes-all" incentive to gain (and exploit) control. Conversely, if the credit union's sponsor (i.e., the employer) controls the institution, then there is likely to be a more balanced distribution of surplus to all members. This is because employers sponsor occupational credit unions to maximize the total surplus the credit union creates for all employees rather than to maximize the surplus for a particular group of employees. Finally, if local deposit-market competition tends to constrain rate-setting behavior, then the credit union's membership structure shouldn't matter at all in the determination of deposit rates.

This paper explores the member-control, the sponsor-control, and the market-control hypotheses and then tests a key prediction made by each. The test is motivated by our theoretical examina-

William R. Emmons is an economist and Frank A. Schmid is a senior economist at the Federal Reserve Bank of St. Louis. William Bock and Judith Hazen provided research assistance. tion of the pricing of deposits that would be expected under each of the three regimes. Because we present a simple model in which there is no risk, we restrict our empirical analysis to deposit rates. An examination of loan rates, by way of contrast, would require controls for the riskiness of individual borrowers and is rife with complications that would only obscure our simple objective. Furthermore, we assume that each credit union member is either a borrower or a depositor but not both (again, for simplicity).

We hypothesize that, if depositors are in control, they will maximize their own surplus by setting high deposit and loan rates, taking into account local market conditions that constrain their actions. ${ }^{1}$ We will show that the larger the majority that depositors enjoy, the lower deposit rates should be. This is because the number of members that the depositors are able to "exploit" is lower. Thus, we expect a positive relationship between the borrower-to-member ratio and deposit rates, conditional on depositor control of the credit union. We also expect that the loan rate in this regime is independent of the membership distribution, corresponding to the familiar textbook monopoly case for constant marginal costs.

If borrowers are in control, on the other hand, we hypothesize that the credit union chooses relatively low deposit and loan rates to maximize the surplus of borrowers, taking due account of local market conditions. In this regime, the deposit rate is independent of the number of borrowers in the membership, corresponding to the textbook "monopsony" result (monopoly of the buyer, rather than the seller). Meanwhile, a higher number of borrowers implies a higher loan rate, because the number of "exploitable" members is lower.

In summary, the member-control hypothesis implies that, as we examine the membership structure of credit unions in cross-section, deposit rates will rise as the number of borrowers in the membership rises as long as the borrowers are in the minority. Once the majority changes from depositors to borrowers, the deposit rate drops

1 Technically, members buy "shares" or "share drafts" in credit unions rather than make deposits. Instead of interest on deposits, credit union members receive "dividends." We use the terms deposits and interest to avoid any confusion with shares and dividends issued by for-profit firms. 
and remains at a low level, independent of how big the borrower majority is.

The sponsor-control hypothesis of occupational credit unions, by way of contrast, presumes that the welfare of each member is weighted equally. The only reason why deposit rates would be associated with the membership structure in a given credit union would be if deposits were an important marginal source of loanable funds. That is, by virtue of having a high number of borrowers, a credit union would have high loan demand. This higher demand would be met by attracting additional deposit funds from members (existing or new). To do this, a credit union would need to offer higher deposit rates. Thus, when examining the cross-section of occupational credit unions, deposit rates would be higher for credit unions with a high proportion of borrowers in the membership.

Finally, the market-control hypothesis describes a situation in which local depositmarket competition constrains credit union ratesetting behavior completely. In other words, no single credit union could set its own deposit rates below local deposit rates without suffering a deposit outflow. Likewise, it could not set rates above the local market without attracting a huge and unusable deposit inflow (limited by its potential membership, of course). The important point for our purposes is that local market competition, rather than the credit union's number of borrowers or lenders in the membership, would dictate rate-setting behavior.

We analyze a large sample of occupational credit unions that reported financial results at the end of 1997 . We characterize the membership distribution by calculating the ratio of the number of loans to the number of members. Our assumption is that this ratio can serve as a proxy for the number of borrowers in the membership. Our sample contains some occupational credit unions with relatively low loan-to-member ratios, which is consistent with depositor majorities. It also contains observations with loan-to-member ratios so high that borrower majorities can be assumed. We find that observed deposit rates are positively associated with the loan-to-member ratio over virtually the entire range of loan-to-member ratios. This result is consistent with the sponsor-control hypothesis of occupational credit unions but is inconsistent with both the member-control and the market-control hypotheses.

\section{BACKGROUND AND RESEARCH ON OCCUPATIONAL CREDIT UNIONS}

Credit unions numbered 11,392 at year-end 1996, serving some 70 million individual members (U.S. Treasury, 1997, p. 15). Credit-union assets were $\$ 327$ billion, compared with $\$ 5,606$ billion held by commercial banks and thrifts (U.S. Treasury, 1997 , p. 21). Of the 7,068 federally chartered institutions at year-end 1996, about three fourths were occupational credit unions (U.S. Treasury, 1997, p. 19). ${ }^{2}$ One or more firms sponsor each occupational credit union, sometimes providing office space, paid time off for volunteer workers, and other forms of support. The remaining federal credit unions are as follows: (i) singlegroup credit unions of the associational or community type, or (ii) multiple-group credit unions with predominantly associational, community, or more than one type of membership (i.e., several types of membership groups that span the usual classifications). According to a credit union survey in 1987, 79 percent of all Americans who were eligible to join a credit union had done so (American Bankers Association, 1989, p. 29). Given the prominent role of occupational credit unions, a majority of members are in the prime working ages of 25 to 44 (American Bankers Association, 1989, p. 30).

Most members of occupational credit unions easily could (and often do) obtain financial services from a for-profit financial intermediary such as a commercial bank or a thrift institution. Why then do so many employers sponsor credit unions? Hansmann (1996) suggests that occupational credit unions continue to thrive today because employers (sponsors) benefit from them:

Employers can also benefit from having a credit union for their employees. The credit union ties the employees more tightly to the employer, improves the employees' financial situation (and consequently their effective wage), and helps keep the employees out of financial difficulties that may interfere with their work or create bother for the employer (such as garnishment of wages). For these reasons

\footnotetext{
2 We concentrate on federally chartered credit unions because the National Credit Union Association does not vouch for the accuracy of data provided by state-chartered credit unions, which report directly to their state's regulatory authorities.
} 
employers have often helped promote the formation of credit unions, for example, by providing free office space and free time off to the employees who administer them. (Hansmann, 1996, pp. 259-60)

Most credit union sponsors are in nonfinancial businesses, so they may not be wellsuited-or particularly eager - to operate a financial institution. At the same time, credit unions are legally governed by their members on a onemember, one-vote basis. Do the members therefore control occupational credit unions? Or do local market conditions dictate many of the business decisions an occupational credit union must make, such as setting deposit rates?

The possibility of member control is important because there may be (roughly speaking) two distinct types of members: those whose primary reason for joining the credit union is to borrow money and those whose primary reason for joining is to save in the form of insured deposits. If members (or member coalitions) effectively control occupational credit unions, then the relative size of the two groups of members determines how deposit and loan terms are set. Gaining effective control of the credit union would allow one group or the other to skew the credit union's terms in their own favor.

The question of who controls cooperative financial institutions, such as occupational credit unions, is an old one (Taylor, 1971; Flannery, 1974; Smith, Cargill, and Meyer, 1981; Smith, 1984; Hart and Moore, 1996, 1998; Emmons and Mueller, 1997; Emmons and Schmid, 1999a, 2000b). Most studies of this type assume that one group of members, such as depositors or borrowers, controls the cooperative firm. Empirical evidence about credit unions is mixed; some studies find depositor domination and others find borrower domination. Emmons and Schmid (1999a) offer an exception to the usual approach that members control the cooperative financial institution. They assume the sponsor exercises control. This study revisits this question in an attempt to find evidence consistent with the member-control, the sponsor-control, or the market-control hypothesis.

\section{A MODEL OF CONTROL IN OCCUPATIONAL CREDIT UNIONS}

We examine a simple credit union that generates surplus for its members by presenting opportunities to borrow and to deposit funds in an insured account. The supply and demand functions are reduced-form equations that result from household optimization subject to the local deposit-market conditions. To keep the model simple, we do not explicitly model these household decisions but instead postulate the existence of demand and supply functions.

We present three (mutually exclusive) hypotheses regarding effective control of an occupational credit union: (i) the member-control hypothesis, under which a controlling group of members sets deposit and loan rates to maximize its own surplus, (ii) the sponsor-control hypothesis, under which the sponsoring firm sets deposit and loan rates to maximize the total surplus for all members, and (iii) the market-control hypothesis, under which local deposit-market competition dictates the rates every credit union sets.

In our model, all potential credit-union members are identical except that some are borrowers while others are depositors. ${ }^{3}$ We assume that the number of loans is proportional to the number of borrowers, and likewise for depositors. More specifically, we assume that each borrowing member wants one loan and responds to changes in the loan rate by adjusting the size of the loan. ${ }^{4}$ The aggregated demand curve for loans and the aggregated supply curve of deposits are obtained by adding up the individual quantities for each price (loan rate and deposit rate, respectively) for each credit union. We analyze aggregated demand and supply curves to derive hypotheses about optimal rate-setting under the three control regimes analyzed here.

We assume the credit union operates under a zero-profit constraint, given its not-for-profit character. The credit union can lend or borrow in the interbank market at the same rate, $r$. For simplicity, we assume that the demand for loans and the supply of deposits are both linear in the borrowing and the deposit rates, respectively. In indirect form, the loan-demand and deposit-supply schedules facing the credit union are as follows:

\footnotetext{
3 Assuming identical potential members implies that all potential members are also actual members (or the credit union would not have formed). See Emmons and Schmid (1999b, 2000a) for models with endogenous membership decisions.

4 The specific proportionality assumption - that each borrower takes out one loan-allows us to use the ratio of loans to members as a proxy for the number of borrowers in the credit union's membership in the empirical section of the article.
} 


\section{Figure 1}

\section{Sponsor Control: Credit Union Maximizes Total Surplus}

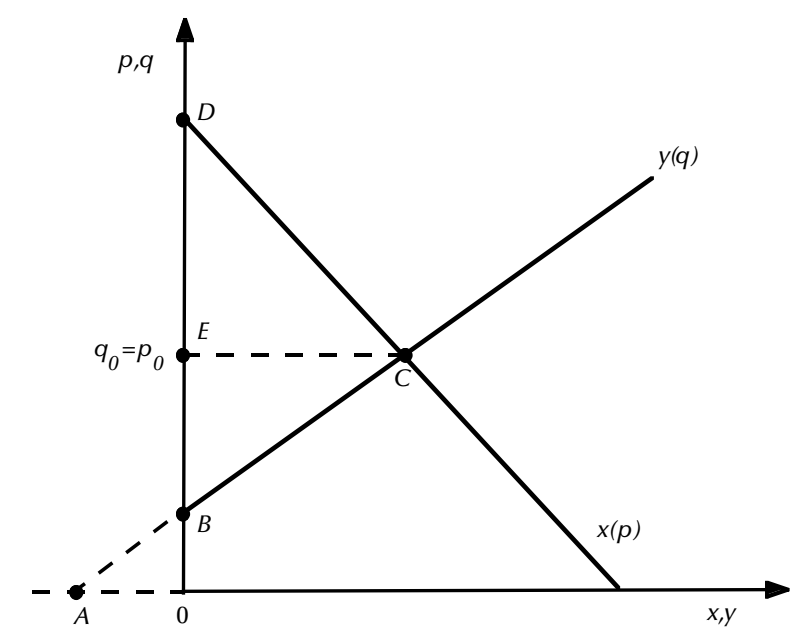

Figure 2

Sponsor Control: Number of Borrowers and Deposit Rates

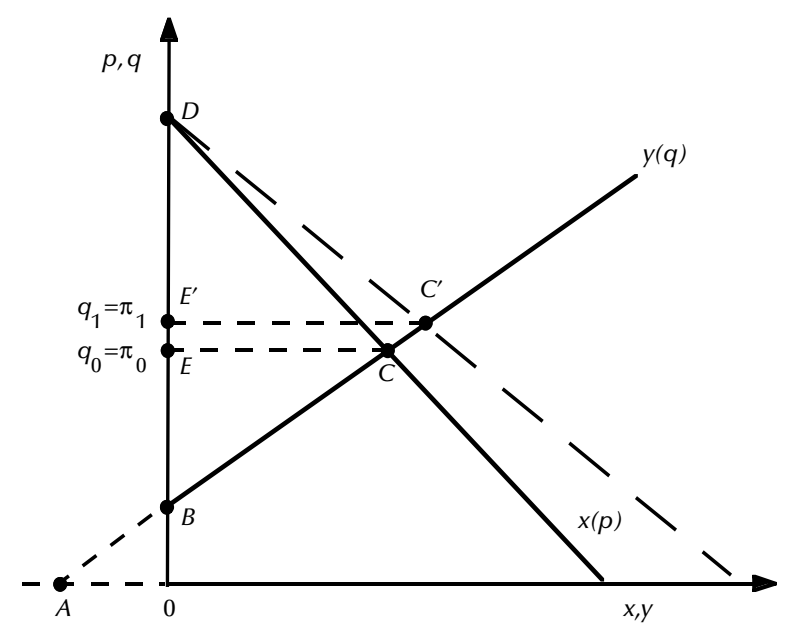

(1a)

$$
\begin{aligned}
& p(x)=a-b x, \quad a, b>0 \\
& q(y)=c+d y, \quad c, d>0,
\end{aligned}
$$

where $p$ and $q$ denote the loan rate and the deposit rate, respectively; $x$ and $y$ are the dollar amounts of loans made and deposits accepted by the bank, respectively; and $a, b, c$, and $d$ are fixed parameters reflecting member preferences. In particular, we assume that the maximum loan rate the borrowers are willing to pay, $a$, exceeds the interbank rate, $r$. Likewise, the minimum deposit rate the depositors are willing to accept, $c$, is below the interbank rate, $r$. The parameters $b$ and $d$ reflect the sensitivities of the loan demand and deposit supply to the credit union's deposit and loan rates, respectively. For simplicity, we assume the credit union has no operating costs. This does not affect the results qualitatively and simplifies the analysis.

\section{Sponsor Control}

Sponsor control implies that the objective of an occupational credit union is to maximize the surplus enjoyed by all members. Figure 1 shows that a sponsor-controlled credit union optimally equates the deposit and loan rates at the level dictated by the intersection of members' demand and supply curves. This result follows from the basic principles of welfare economics. The surplus of borrowers is the area under the demand curve and above the optimal loan rate, $p_{0}$ (triangle ECD). Intuitively, the surplus equals the difference between the borrowers' aggregate willingness to pay for loans (indicated by the demand curve) and the amount that they actually pay. Similarly, the surplus of the depositors is equal to the difference between the amount of interest they receive and the amount of interest they are willing to accept, which is reflected in the deposit supply curve. This surplus is the area between the supply curve and the optimal deposit rate, $q_{0}$ (triangle BCE).

Figure 2 compares two credit unions with the same number of depositors (the same deposit supply curve) but with different numbers of borrowers. The credit union with the higher number of borrowers (and thus the higher borrower-tomember ratio) has a deposit and loan rate equal to $q_{1}$, compared with the lower value $q_{0}$, which is the rate of the credit union with the smaller borrowerto-member ratio. ${ }^{5}$ This simple analysis leads to our first hypothesis:

Hypothesis 1: Sponsor Control. The deposit rate strictly increases as the number of members who are borrowers increases.

A later section discusses our strategy for testing this hypothesis.

5 The demand curve rotates upward - rather than tracing out a parallel upward shift-because each individual borrower's willingness to pay is identical and the credit union's aggregate demand curve represents a horizontal summation of individual loan demands. 


\section{Member Control}

Member control of a cooperative firm inevitably leads to conflicts of interest if there is more than one type of member. Control of decision-making determines how much surplus the credit union will generate and how this surplus will be distributed among the members. The key difference between a member-controlled credit union and one that is controlled by a sponsor is that, in the former case, the dominant member group will act like a monopoly with respect to minority members. The latter will act like a "benevolent dictator," resulting in the competitive market outcome.

Depositor Control. If depositors are in control they will maximize their surplus by solving the following optimization problem:

$$
\underset{p, q}{\operatorname{Max}} \frac{q-c}{2} y(q)
$$

subject to

$$
\begin{gathered}
0=p \cdot x(p)-q \cdot y(q)+r \cdot[y(q)-x(p)] \\
p \geq q .
\end{gathered}
$$

The quantity to be maximized is the area above the deposit-supply curve, which is determined by the choice of the deposit rate, $q$. Constraint (2b) sets out the credit union's zeroprofit constraint and reflects the fact that interbank borrowing or lending is used to offset imbalances in the amount of loanable funds demanded and supplied by members at the chosen interest rates. Constraint (2c) excludes profitable roundtrip transactions in which members finance high-rate deposits by borrowing low-rate funds from the credit union.

Solving the maximization problem shown above, the optimal deposit rate, $q^{*}$, and the optimal loan rate, $p^{*}$, are as follows ${ }^{6}$ :

$$
\begin{gathered}
q^{*}=\frac{c+r+\sqrt{(c-r)^{2}+\frac{d}{b}(a-r)^{2}}}{2} \\
p^{*}=\frac{a+r}{2} .
\end{gathered}
$$

Equation (3a) shows that, if we compare two credit unions that differ in the number of borrowers (i.e., in the demand parameter $b$ ) but are otherwise comparable, the credit union with the higher number of borrowers (lower value of $b$ ) has the higher deposit rate, $q^{*}$. This reflects the fact that with a higher borrower-to-member ratio there are more minority members who can be "exploited" in terms of high loan rates, which, in turn, allows the credit union to pay higher deposit rates. A depositor-controlled credit union chooses the monopoly loan rate, $p^{*}$, and pays $q^{*}$ on deposits, producing surplus for depositors. The credit union has excess deposits, in the amount $y\left(q^{*}\right)-x\left(p^{*}\right)$, which are lent in the interbank market. In effect, the monopoly profit obtained through lending the amount $x\left(p^{*}\right)$ is distributed to depositors in the form of deposit rates that are higher than interbank rates. Note that the loan rate changes in response to changes in the membership structure only if control of the credit union also switches from depositors to borrowers.

Borrower Control. Borrowers will control the credit union if they constitute a large enough fraction of the membership. Under borrower control, the credit union's maximization program is the following:

$$
\operatorname{Max}_{p, q} \frac{a-p}{2} x(p)
$$

subject to

$$
0=p \cdot x(p)-q \cdot y(q)+r \cdot[y(q)-x(p)]
$$

$$
p \geq q \text {. }
$$

In this case, the quantity to be maximized is the area below the loan demand curve, which is determined by the choice of the loan rate, $p$. The optimal deposit rate, $q^{*}$, and the optimal loan rate, $p^{*}$, are as follows ${ }^{7}$ :

$$
\begin{gathered}
q^{*}=\frac{c+r}{2} \\
p^{*}=\frac{a+r-\sqrt{(a-r)^{2}+\frac{b}{d}(r-c)^{2}}}{2} .
\end{gathered}
$$

$$
\begin{aligned}
& 6 \text { The second solution to the deposit is } \\
& \qquad q^{*}=\left(c+r-\left[(c-r)^{2}+\frac{d}{b}(a-r)^{2}\right]^{\frac{1}{2}}\right) / 2 .
\end{aligned}
$$

The solution represents a minimum in the depositors' surplus. We assume the solution is interior (constraint (2c) is not binding).

7 The second solution to the loan rate is

$$
p^{*}=\left(a+r+\left[(a-r)^{2}+\frac{b}{d}(r-c)^{2}\right]^{\frac{1}{2}}\right) / 2 .
$$

The solution represents a minimum in the borrowers' surplus. Again, we assume $p<q$. 


\section{Figure 3}

Member Control: Loan-to-Member Ratio and Deposit Rates

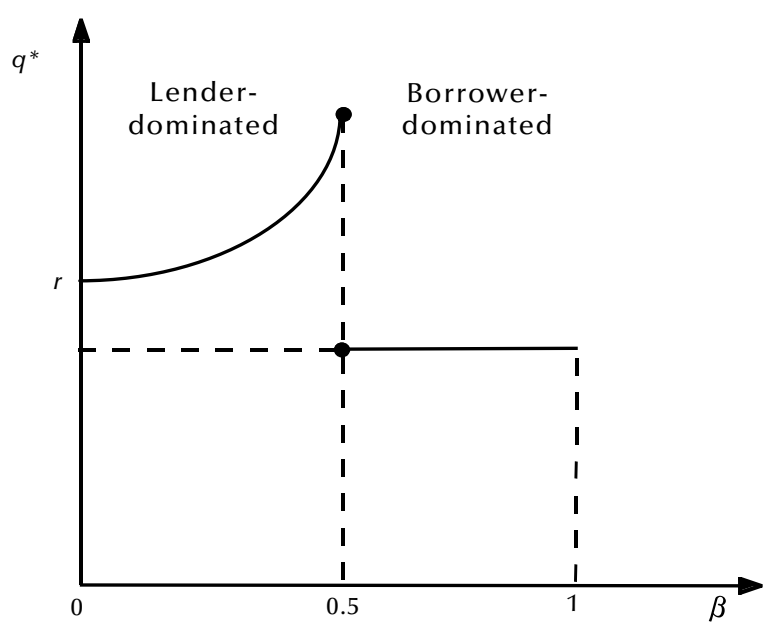

In a way analogous to the case considered above in which the loan rate was invariant, the deposit rate is unaffected by changes in the number of borrowers (represented by variations in the loan demand parameter, $b$ ). Holding all else equal, the optimal loan rate increases with the number of borrowers because progressively more borrowers must share the surplus generated by low-priced deposits. A borrower-controlled credit union sets a relatively low lending rate, $p^{*}$, and attracts more loan demand, $x\left(p^{*}\right)$, than there is deposit supply, $y\left(q^{*}\right)$. The shortfall in deposit funding is met by borrowing in the interbank market at rate $r$. In effect, the monopsony profits earned by the credit union on deposits collected at rate $q^{*}$ are distributed to borrowers in the form of a belowinterbank market lending rate of $p^{*}$. In this case it is the deposit rate that is insensitive to small changes in the membership structure as long as these changes do not transfer control away from borrowers.

Implications of Member Control. When combining the two variations on the theme of member control, two features are noteworthy. First, the deposit rate is greater throughout the depositordominated regime than it is anywhere in the borrower-dominated regime. This makes intuitive sense because depositors who exercise control over the credit union will capitalize on this fact and pay themselves a higher deposit rate. Second, the fact that control must shift from depositors to borrowers at some point as the percentage of borrowers in the membership increases implies that there is a discontinuity in the schedule of optimal deposit rates. Figure 3 displays these two features, where $\beta$ is the fraction of members who are borrowers. The results of our analysis of the case of member control lead us to the following hypothesis:

Hypothesis 2: Member Control. The deposit rate strictly increases as the number of borrowers increases if a credit union is under depositor control. The deposit rate is constant and takes on its global minimum value if a credit union is under borrower control.

\section{Market Control}

Thus far, we have focused only on the internal control features of occupational credit unions. It is clear, however, that external factors may constrain the ability of a controlling group of credit union members to extract surplus. If price competition is strong in local deposit or loan markets, minority members may threaten to leave the credit union to improve the terms they receive. This leads to our third testable hypothesis:

Hypothesis 3: Market Control. Deposit rates are independent of credit-union membership structure (the fraction of members who are borrowers).

\section{EMPIRICAL EVIDENCE}

We use the loan-to-member ratio as a proxy for the borrower-to-member ratio. Our sample includes occupational credit unions with loan-to-member ratios so low that depositors almost certainly are in the majority. The sample also contains credit unions in which the loanto-member ratio is so high that a borrower majority appears inevitable. Given the wide range of membership structures that we observe and our model's predictions, a deposit rate that strictly increases as the loan-to-member ratio increases would support Hypothesis 1, namely, sponsor control of occupational credit unions. A deposit rate that initially increases, drops discontinuously, and then remains constant as the loan-to-member ratio increases would support Hypothesis 2, namely, member control. A pattern of deposit rates that is completely unrelated to the loan-to-member ratio would support Hypothesis 3, namely, market control. Note that these qualitative predictions about the dataset do not require us to identify which credit unions are depositor-controlled and which are borrower-controlled (if any). 


\section{Table 1}

\section{Distribution of Credit Unions by Type of Membership}

\begin{tabular}{|c|c|c|c|c|}
\hline \multirow[b]{2}{*}{ Type of membership (TOM) } & \multicolumn{2}{|c|}{ TOM codes * } & \multicolumn{2}{|c|}{ Number of credit unions } \\
\hline & $\begin{array}{l}\text { Single-group } \\
\text { credit unions }\end{array}$ & $\begin{array}{l}\text { Multiple- } \\
\text { group credit } \\
\text { unions }\end{array}$ & $\begin{array}{l}\text { Single-group } \\
\text { credit unions }\end{array}$ & $\begin{array}{l}\text { Multiple- } \\
\text { group credit } \\
\text { unions }\end{array}$ \\
\hline Educational & 4 & 34 & 327 & 494 \\
\hline Military & 5 & 35 & 39 & 130 \\
\hline Federal, state, local government & 6 & 36 & 417 & 649 \\
\hline Manufacturing & $10-15$ & $40-49$ & 843 & 871 \\
\hline Services & $20-23$ & $50-53$ & 585 & 779 \\
\hline Totals & & & 2,211 & 2,923 \\
\hline
\end{tabular}

* National Credit Union Association (NCUA), Instruction No. 6010.2, July 28, 1995.

\section{Table 2}

\section{Descriptive Statistics}

\begin{tabular}{lccccc} 
& Minimum & Median & Mean & Maximum & Standard deviation \\
\hline Deposit rate & 0.004 & 0.038 & 0.038 & 0.089 & 0.008 \\
Loan-to-member ratio & 0.009 & 0.447 & 0.471 & 1.859 & 0.177 \\
Herfindahl index & 0.053 & 0.208 & 0.208 & 1 & 0.095 \\
\hline
\end{tabular}

We use a semi-parametric estimation method to address the possibility that the deposit rate is nonlinear in the loan-to-member ratio (as indeed it appears to be). This ratio is included in the nonparametric part of the regression along with a constant regressor, whereas the parametric part of the regression contains a set of normalizing regressors. The normalizing regressors are four zero-one indicator variables that represent the type of membership (TOM) categories shown in Table 1, with educational credit unions serving as the numeraire unit (the excluded category). The nonparametric methodology allows the relationship between the deposit rate and the loan-tomember ratio to take on a (smooth) functional form. The assumption of a smooth relationship between the loan-to-member ratio and the deposit rate is not restrictive if the relationship between the loan-to-member ratio and the borrowerto-depositor ratio is stochastic. For example, the number of loans per borrower might not be the same for all credit unions in the sample. For details on the econometric methodology, see the Appendix.

We examine a subset of all federally chartered and federally insured occupational credit unions that reported financial information at the end of 1997 (see the Appendix for details on construction of the dataset and the variables used). Table 1 provides a breakdown of our sample according to the type of membership group characterizing each credit union. The Table distinguishes between credit unions with a single common bond and those with multiple common bonds. Overall, 2,211 credit unions in our sample had a single common bond ( 43 percent of the sample), whereas 2,923 credit unions ( 57 percent of the sample) had multiple common bonds among their membership.

\section{Membership Structure and Deposit Rates}

The estimated relationship between deposit rates and the loan-to-member ratio in our sample is displayed in Figure 4 by the solid line. In essence, the figure depicts the expected deposit rate (vertical axis) for an occupational credit union with a given loan-to-member ratio (horizontal axis). Ninety percent confidence intervals for the point estimates are shown as dashed lines. ${ }^{8}$

\footnotetext{
8 For econometric reasons we discarded 627 observations with zero values for the deposit rates. We also discarded 55 observations of loan-to-member ratios greater than 2 because these seemed to be aberrations or reporting errors. For instance, one credit union reported a ratio of loans to members that equaled 365 .
} 


\section{Figure 4}

\section{Impact of Loan-to-Member Ratio on Deposit Rates}

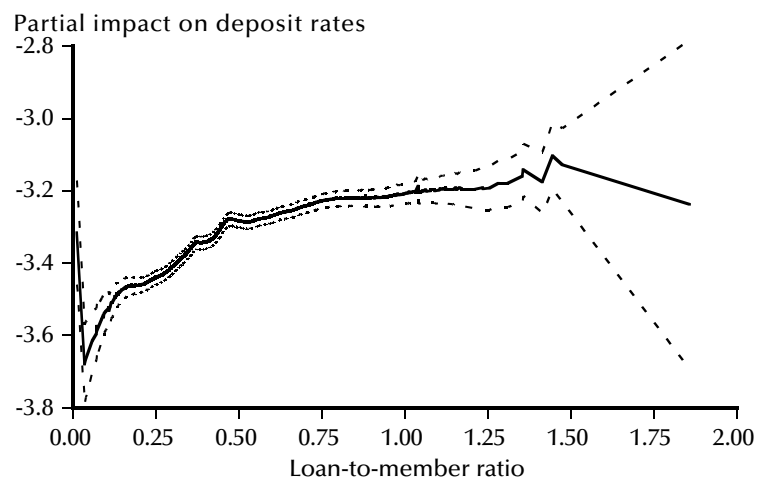

Estimated relationship between loan-to-member ratio and deposit rates

- - - - Limits of a 90 percent confidence interval

\section{Table 3}

\section{Parametric Variables from the}

Semi-Parametric Regression

Type of membership

\begin{tabular}{lcc} 
(TOM) codes & Coefficient & t-Statistic \\
\hline Military & $2.385 \times 10^{-2}$ & $1.795^{*}$ \\
Government & $2.087 \times 10^{-2}$ & $2.239^{* *}$ \\
Manufacturing & $4.560 \times 10^{-2}$ & $5.053^{* * *}$ \\
Services & $4.178 \times 10^{-2}$ & $4.480^{* * *}$ \\
Number of & 5,134 & \\
observations & & \\
$* / * * / * *$ Significant at $\mathbf{1 0 / 5 / 1}$ percent levels (two-tailed tests).
\end{tabular}

Figure 4 indicates a positive association between the loan-to-member ratio and credit union deposit rates over the bulk of observed loan-to-member ratios. The intercept is not identified in regressions of this type, so only vertical distances in the figure are meaningful (not the level itself). The tight confidence intervals over the central region in the figure (where the overwhelming number of credit-union observations lie) imply that the slope of the relationship is reliably positive. Confidence intervals widen dramatically and the point estimates appear erratic at extreme values of the loan-to-member ratio because there are very few observations in those ranges. Figure 4 therefore provides visual evidence to support the sponsor-control hypothesis of occupational credit unions. That is, it does not appear that member control switches from depositors to borrowers as the loan-to-member ratio increases in the cross-section of credit unions. Nor does it appear that loan-to-member ratios and deposit rates are completely unrelated, as the market-control hypothesis requires. Instead, the upward-sloping relationship is consistent with the sponsor-control regime where the membership structure and deposit rates are related because deposits are an important marginal source of funding for loans. ${ }^{9}$

Table 3 displays the coefficients from the parametric part of our semi-parametric regression equation. As mentioned above, the regressors are zero-one indicator variables that represent the type of membership with educational credit unions serving as the numeraire unit. The significant coefficients on TOM codes indicate that there are variations in the ability or willingness of occupational credit unions to pay higher deposit rates among different types of sponsors.

\section{CONCLUSIONS}

This article seeks to answer the question of how occupational credit unions set deposit rates. We investigate three potential control regimes under which occupational credit union deposit rates might be set, namely, member control, sponsor control, and market control.

If members control occupational credit unions, we would expect a positive relationship between the extent of loan demand and the deposit rate, conditional on depositor control of the credit union. If borrowers are in control, however, we expect the deposit rate to take on a value that is lower than what we would observe in the depositor-dominated regime; also, conditional on borrower control, we expect the deposit rate to be independent of the membership structure. Thus, the member-control hypothesis implies that, in a cross-sectional snapshot of many different credit unions, the deposit rate would be higher whenever the borrower-to-member ratio is higher so long as depositors are in control. For sufficiently high values of the borrower-to-member ratio, however, borrowers would be in the majority. For these

\footnotetext{
${ }^{9}$ We experimented with other empirical specifications including one in which a county-level Herfindahl index was used as a conditioning variable to represent the intensity of deposit-market competition. Details on the construction of this variable are in the Appendix. This variable was never significant, however, so we do not report results from models in which it was used.
} 
credit unions, the deposit rate would take on its minimum value in the sample and would be completely independent of the membership structure.

The sponsor-control hypothesis of occupational credit unions, by way of contrast, predicts that deposit rates would be higher, the greater the proportion of borrowers in the membership. This is because deposits are an important marginal source of funds for meeting loan demand, and higher deposit rates are necessary to attract additional loanable funds.

Finally, the market-control hypothesis suggests that occupational credit union deposit rates and the loan-to-member ratios should be completely unrelated. Local competition would dictate deposit rates and there would be no statistical relationship between membership structure and deposit rates whatsoever.

Using data from a large sample of occupational credit unions observed at the end of 1997, we find that deposit rates are positively associated with a measure of the credit union's loan demand throughout most of the range of observed loan-to-member ratios. This finding is consistent with the sponsor-control hypothesis of occupational credit unions but not with the membercontrol or the market-control hypothesis. This result supports the theoretical approach taken in Emmons and Schmid (1999a), where effective sponsor control of occupational credit unions was assumed.

Thus, it appears that Hansmann's (1996) suggestion-that employers sponsor and operate occupational credit unions to provide surplus to all of their employees - is a better description in practice than the view that they are subject to capture by a subset of members or that local competition dictates credit union rates completely.

\section{REFERENCES}

American Bankers Association. The Credit Union Industry: Trends, Structure, and Competitiveness, 1989.

Emmons, William R. and Mueller, Willy. "Conflict of Interest Between Borrowers and Lenders in Credit Cooperatives: The Case of German Cooperative Banks." Working Paper, Federal Reserve Bank of St. Louis, 1997.

and Schmid, Frank A. "Wages and Risk-Taking

in Occupational Credit Unions: Theory and Evidence." Federal Reserve Bank of St. Louis Review, March/April 1999a, 81(2), pp. 13-31. and "Credit Unions and the Common Bond.” Federal Reserve Bank of St. Louis Review, September/October 1999b, 81(5), pp. 41-64. and "Bank Competition and Concentration: Do Credit Unions Matter?" Federal Reserve Bank of St. Louis Review, May/June 2000a, 82(3), pp. 29-42.

and "Pricing and Dividend Policies in Open Credit Cooperatives." Working Paper 2000-008A, Federal Reserve Bank of St. Louis, March 2000b.

Flannery, Mark J. "An Economic Evaluation of Credit Unions in the United States." Research Report No. 54, Federal Reserve Bank of Boston, 1974.

Hansmann, Henry. The Ownership of Enterprise. Cambridge, MA: Harvard University Press, 1996.

Hart, Oliver and Moore, John. "Cooperatives vs. Outside Ownership.” Working Paper, Harvard University, 1998.

and "The Governance of Exchanges: Members' Cooperatives versus Outside Ownership." Oxford Review of Economic Policy, Winter 1996, pp. 53-69.

Smith, Donald J. "A Theoretic Framework for the Analysis of Credit Union Decision Making." Journal of Finance, September 1984, 39(4), pp. 1155-68.

; Cargill, Thomas F. and Meyer, Robert A. "An Economic Theory of a Credit Union.” Journal of Finance, May 1981, pp. 519-28.

Taylor, Ryland A. "The Credit Union as a Cooperative Institution.” Review of Social Economy, September 1971, pp. 207-17.

U.S. Treasury Department. Credit Unions. Washington, DC: U.S. Government Printing Office, 1997.

\section{Appendix}

\section{DATASET AND VARIABLES}

\section{The Dataset}

We analyze a dataset comprising all federally chartered and federally insured credit unions at the end of 1997. The dataset was obtained from the Report of Condition and Income for Credit Unions (NCUA 5300, 5300S) and produced by the 
National Credit Union Administration (NCUA). These reports are issued semi-annually in June and December. We used the December data. The flows in the December income statements include the entire year of 1997 .

We concentrate on the following types of membership (TOM) groups among occupationally based credit unions: educational; military; federal, state, and local government; manufacturing; and services. Thus, we do not include community credit unions, associational credit unions, or corporate credit unions. Lists of TOM classification codes are from the NCUA (Instruction No. 6010.2, July 28, 1995).

We excluded observations for any of the following reasons:

- Missing TOM codes.

- Activity codes other than "active."

- Number of members or potential members not greater than one (applies to actual and to lagged values).

- Number of loans to members equal to zero (applies to actual and to lagged values).

- Ratio of lagged number of loans to lagged number of members greater than two.

- Nonpositive values for total assets or lagged total assets.

- Dividend on shares equal to zero.

We calculated county-specific Herfindahl indexes as measures of concentration of the local banking market. A Herfindahl index is defined as the sum of squared market shares. We measured market shares as the fraction of total commercial-bank and Bank Insurance Fund (BIF)-insured thrift deposits (as of June 30) within a county (or independent city) based on FDIC Summary of Deposits data. These data are available online at < http://www2.fdic.gov/sod/ >. Table 2 provides an overview of the dataset.

\section{Definition of Variables}

Definitions of variables and underlying data sources are listed below. Relevant item numbers are in brackets for data taken from the Report of Condition and Income for Credit Unions, produced by the National Credit Union Administration.

Dependent Variable. Deposit rate: Natural logarithm of the ratio of dividends on shares [CUSA6091] and total shares and deposits [CUSA6091]. We use the natural logarithm because the deposit rate has a lower bound at zero.

\section{Independent Variables}

1. Loan-to-member ratio: Number of loans to members divided by number of members. The number of loans to members was obtained as the difference between the number of total loans [CUSA1262] and the number of loans that were purchased or extended to non-members [CUSA1205]. The loan-tomember ratio was lagged by one year.

2. TOM code variables: Equal to one if the credit union is of a specific type (military, government, manufacturing, or services). Because we use an intercept in the nonparametric part of the semi-parametric regression, the TOM code variable for the educational credit union was dropped.

3. Herfindahl index: Sum of squared market shares of total commercial-bank and BIF-insured thrift deposits. By definition, the Herfindahl index is greater than zero; its maximum value is one. The Herfindahl index was lagged by one year. Results using the Herfindahl index are not reported in the text; see footnote 7 .

\section{Econometric Method}

We use a semi-parametric model to allow the influence of the loan-to-member ratio on the dependent variable to be nonlinear. The parametric part of the model contains zero-one variables that indicate the TOM code. In particular, we use a semi-parametric model of a credit union's participation rate of the form:

$$
y_{i}=f\left(x_{i}\right)+x_{p i} \cdot \beta_{p}+\varepsilon_{i}, i=1, \ldots, n,
$$

where $y_{i}$ is the $i$ th observation of the dependent variable; $x_{i}$ is a vector consisting of the $i$ th observation of the explanatory variables in the nonparametric part of the model, the loan-to-member ratio, and (in unreported versions of the model) the Herfindahl index; $x_{p i}$ is a row vector consisting of the ith observation of the explanatory variables of the linear (parametric) part of the model; $\beta_{p}$ is a column vector of the parameters of the linear part of the model; and $\varepsilon_{i}$ is the $i$ th realization of the error term. For details on this econometric approach, see the Appendix in Emmons and Schmid (1999a). 